\title{
Features of the Cluster Structures Development in the Economy Digitalization Conditions
}

\author{
Anatoliy Asaul \\ Department of Construction Economics \\ and Housing \\ St. Petersburg State University of \\ Architecture and Civil Engineering \\ St. Petersburg, Russia \\ http://orcid.org/0000-0002-7415-4737 \\ Lesia Bilorusets \\ Department of Accounting, Audit and \\ Taxation \\ Khmelnytskyi National University \\ Khmelnytskyi, Ukraine \\ be11607@i.ua
}

\begin{abstract}
The article clarifies the essence and peculiarities of the manifestation of the digital economy, which develops at an exponential rate, radically changing the essence of business. The role of clusters in combining the potential of science, business and the state to ensure socio-economic development is shown. The preconditions, positive and negative factors and tasks of digitization of economic processes are outlined, the algorithm of their implementation on the basis of the system approach and goal structuring is constructed, their influence on the conditions of functioning and structural changes of cluster systems as the basis for the development of the world economy of a new type is revealed.
\end{abstract}

Keywords - solidary information economy, digital economy, cluster systems, digitalization.

\section{INTRODUCTION}

Transformational changes and restructuring of the national economy are accompanied by the intellectualization of all areas of economic activity, innovative development and the transformation of knowledge into basic resources, determines new conditions for the functioning of business entities and their associations. Research aimed at determining the role of cluster systems of the information society development and formation acquire a special scientific and practical significance.

Therefore, the article purpose is to find new approaches for the digital technologies of cluster systems effective implementation that requires solving a certain range of tasks related to optimal planning of the clusters economic processes digitalization based on the system and algorithmic approaches.

The formation and development of competitive national economy are impossible without the use of all available mechanisms accelerating reformation and improvement of domestic social and economic processes. Such an approach to studying the problems of increasing the national economy efficiency poses new challenges and requires new ways to solve them. First of all, it is about the choice of a competitive economy model, which is defined by scientists as a solidary information economy, providing a number of advantages for transition to a new qualitative stage of cooperation between state authorities, science and business, and which is the basis

of digital economy. The latter is a type of economy characterized by active implementation and use of digital technologies, and its rapid development involves structural transformation of social and economic systems and realization of innovations' potential. Global practice shows that successful realization of new economic development directions is possible due to economic processes clustering that have potential to increase competitiveness through the prism of economic processes digitization. Purpose of the study is to investigate peculiarities of digital economy development and its impact on production and economic processes and structural changes in business. In order to achieve this goal, it is necessary to solve a number of tasks: to identify the advantages and problematic aspects of economic processes digitization; to allocate structural changes in cluster systems under the influence of digital technologies development aimed at their important prerequisite realization - organizing new type of cooperation between state authorities, science and business that cluster structures can provide.

\section{METHODOLOGY}

The study of main economic theory provisions was carried out using the methods of analysis, system approach and clusterization principles. General scientific methods, such as theoretical generalization, synthesis, and comparison, were used. The method of analysis allowed revealing problematic aspects of digitalization and highlighting its positive influence factors on business development, in particular, cluster structures. Basing on empirical research and analysis of scientific sources results, the main cluster structures elements and their interconnections are distinguished under conditions of economic processes digitalization. 


\section{RESULTS AND DISCUSSIONS, SUMMARY OF MODERN RESEARCH.}

Rapid development of science and technology leads to the significant economic information increase and the emergence of terms describing new economic phenomena and economic processes associated with globalization, integration and informatization of all global economy spheres. That is why today such concepts and categories as «information and communication management», «information economy», «innovation economy», «new economy», «information society», «knowledge economy» etc. are widely used in scientific community and in practice [ $2 ; 3 ; 7 ; 8]$. These concepts have certain differences, but they all are based on knowledge, information systems and computer technologies, human capital, innovations and a combination of the development of science and technology in the global economic space. Due to this they can be synonymous at certain stages of the scientific research.

Economic phenomena and processes described by these terms reflect a new era of global development, where a solidary information economy comes to replace a market economy. During the previous decade this new type of economy has been theoretically substantiated by domestic and foreign scientists. Among them are V. Hlushkov, V. Loiko, Ye. Lutsenko, A. Orlov, S. Shtovba etc. [4; 9] The most important features of solidary informational economy are as follows: planning of society development, balancing and growth of social standards for all categories of workers, equality in employer - employee relationship, projected entry of countries into the global economy and recognition of solidary information economy as the basis of digital economy. The fact that $20 \%$ of the world economy GDP is directly related to the sectors of economy with digitalization, and processes' automation due to robotics increases by $60 \%$ per year proves the need of high emphasis to be paid to digital economy [2]. Ignoring these trends will inevitably result in a loss of competitiveness of individual companies, their associations, and the country in general in the nearest future.

Consequently, the objective reality of global economy transformational changes over the past decades requires the constructive mechanisms for further communication between science, government and business aimed at developing strategies to meet technological challenges of the new information age. In this regard, Ukraine's first task now is to develop a competitive economy model, stimulating priority sectors' development, which has an economic potential for increasing competitiveness through the prism of economic processes' digitization [5]. As the experience of highly developed economic systems testifies, cluster systems are the most efficient basis for economic growth model [10].

Industrialization of state's industrial complex stipulates for new cooperation forms between enterprises and research institutions to be created among which a cluster form of social and economic relations organization deserves special attention [6]. Economy's clustering means an industrial complex created on the basis of concentrating manufacturing elements, economic and financial interests, scientific and educational, and other parts of social and economic system. It is vital that there is no confrontation between big companies and small and medium business within a cluster approach. On the contrary large-scale projects, industrial and social programs are intensified within clusters. Moreover clusters stimulate both depressed regions recovery and lossmaking enterprises financial invigoration. International experience proves clustering to provide world standards of industrial economic development due to creating interbranch cluster systems with industrial relations and new technology, uniting tens or hundreds of big, middle and small enterprises [1]. One branch competitive advantages favour adjacent branches' competitive advantages within one cluster thus promoting common high-technology system formation [12]. So the main factor of national economic development strategic directions implementation is its reconstruction with raising cooperation priority of governmental, scientific and business institutions and clustering processes. It should also be aimed at high-technological, intellectual, informational, and science intensive production with quality products highly demanded in the global market. The research results of global and national experience of industrial clusters functioning show that the cluster development model most fully takes into account the forms of constantly changing competition and main sources of competitive advantage. The cluster method allows realizing the most important relations in technologies, skills, information, marketing and consumer needs, which are characteristic for a whole range of firms and industries. These relationships have a decisive influence on the innovations' direction and pace, as well as on the final product competitiveness, which is important for the digitization of economic activity. Today digital economy, which develops at an exponential rate, appears a fundamental change of business, dematerialization, demonetization and democratization of all sectors of the national economy [9].

Accordingly, cluster structures, like all business entities regardless of their scope, are already affected by both positive and negative factors of digital economy, the main of which are presented in Table 1.

TABLE 1. MAIN ADVANTAGES AND DISADVANTAGES OF DIGITAL ECONOMY DEVELOPMENT

\begin{tabular}{|l|l|}
\hline \multicolumn{1}{|c|}{$\begin{array}{c}\text { Advantages of digital } \\
\text { economy }\end{array}$} & \multicolumn{1}{c|}{$\begin{array}{c}\text { Disadvantages of } \\
\text { digital economy }\end{array}$} \\
\hline $\begin{array}{l}\text { Production and economic processes } \\
\text { automation and increasing their } \\
\text { efficiency }\end{array}$ & $\begin{array}{l}\text { Rapid pace of technological } \\
\text { change }\end{array}$ \\
\hline $\begin{array}{l}\text { Flexible production launch bringing } \\
\text { higher profits }\end{array}$ & $\begin{array}{l}\text { Hyperdistribution of business } \\
\text { taking into account global } \\
\text { electronic networks })\end{array}$ \\
\hline $\begin{array}{l}\text { Using convergence opportunities, } \\
\text { where product data is available at all } \\
\text { stages of its lifecycle - from design } \\
\text { to maintenance }\end{array}$ & $\begin{array}{l}\text { Growth of new distributed data } \\
\text { sources for decision } \\
\text { informational support in real } \\
\text { time }\end{array}$ \\
\hline Improving corporate culture & Cybersecurity problems \\
\hline $\begin{array}{l}\text { Improving the management system } \\
\text { efficiency }\end{array}$ & $\begin{array}{l}\text { Constant growth of user needs in } \\
\text { current and contextual } \\
\text { information }\end{array}$ \\
\hline $\begin{array}{l}\text { Use of robotics and artificial } \\
\text { intelligence }\end{array}$ & $\begin{array}{l}\text { Changes in cluster members } \\
\text { interaction and their information } \\
\text { exchange }\end{array}$ \\
\hline $\begin{array}{l}\text { Continuous training of employees, } \\
\text { development of education industry }\end{array}$ & $\begin{array}{l}\text { Optimization of the individual } \\
\text { categories of specialists number }\end{array}$ \\
\hline $\begin{array}{l}\text { Personification of contact with the } \\
\text { customer }\end{array}$ & $\begin{array}{l}\text { Difficulty in assessing the } \\
\text { reliability of information }\end{array}$ \\
\hline
\end{tabular}


Production and scientific relations in cluster structures allows them to make a policy of being ahead of the average global pace of the scientific and technological progress introduction. That is why network national systems are a powerful engine for digital economy development and a national security mechanism against the threat of corporate globalism.

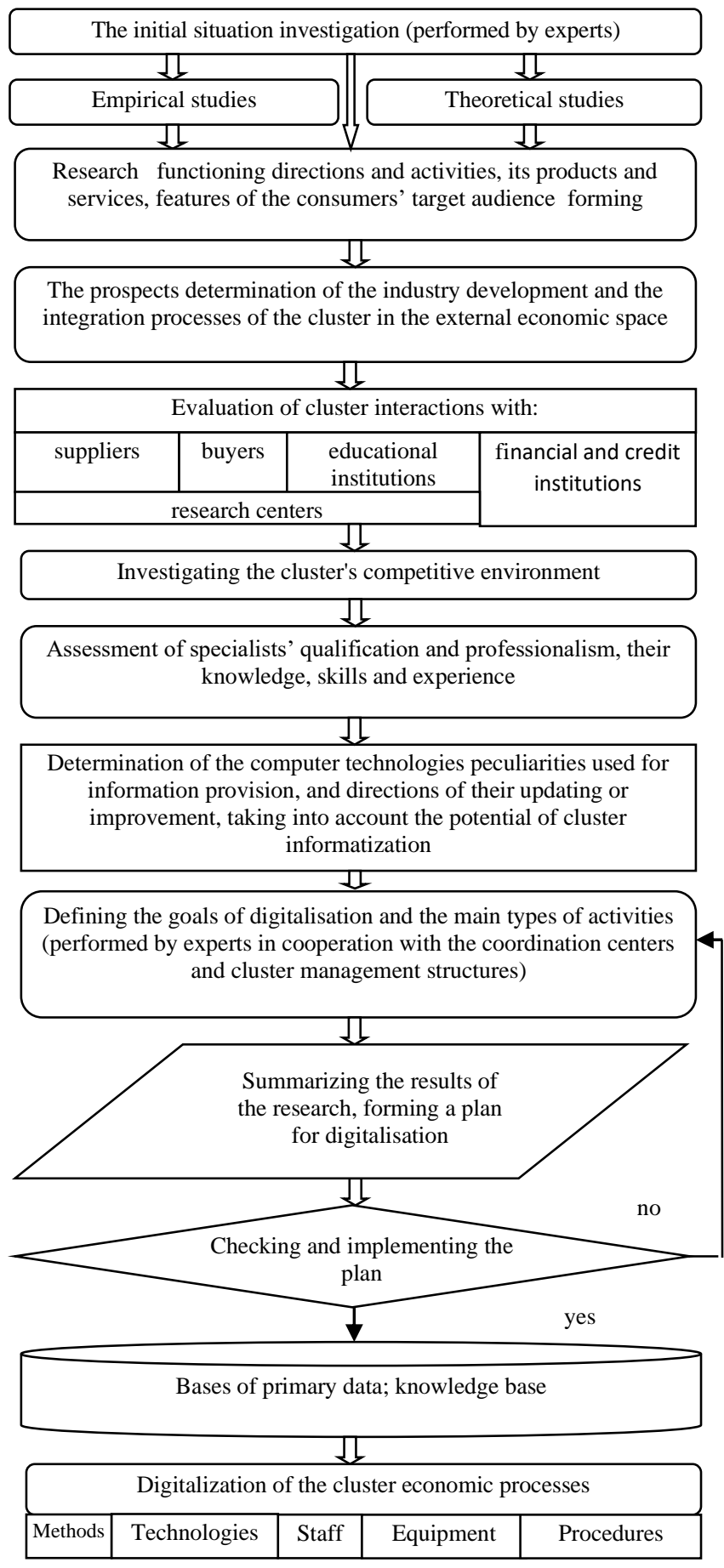

Fig. 1. The model of digital technologies in cluster structures

Clusters protect national producers from global monopolies, thereby protecting their own states-nations and regional economies [11]. The concept of cluster is a new way to detect the growth of national economy, economy of the region and economy of the enterprise, and also points to new roles of companies, governments and international organizations seeking to increase their competitiveness in economic processes digitalization. Thus clusters as complex structures with many internal and external connections need perspective digitization plans to enable further innovative ideas generating and their implementation possibilities. A schematic model of the digital technologies implementation in cluster structures is presented in Fig. 1

The main goals of digital development are: economic growth and attracting investments; transformation of economic sectors into competitive and efficient ones; technological and digital industrial modernization and hightech industries creation; accessibility of the digital world's benefits and opportunities; implementation of human resources; digital industries and digital entrepreneurship development. Cluster being a complex social and economic system with a multifunctional production and capital management mechanism, transition of clusters to digitalization must be well-grounded and implemented stageby-stage. Since the cluster is a complex socioeconomic system, with a multifunctional production and capital management mechanism, so the transition of clusters to digitalization must be grounded and implemented in a phased manner, as the implementation of local investment projects, with the definition of a range of experts - highly skilled professionals who will provide an integrated approach to the implementation of digital platforms on a unified basis, for the purposeful integration of cluster elements.

The formation of a group of experts is carried out in the first stage. At the same stage, the experts determine the peculiarities of the cluster's functioning, the level of information systems and computer technologies implementation, the number of local investment projects and their alternatives, and indicators of advantages in the form of technical, intellectual, financial, economic, social and other indicators that can be represented by mathematical expression:

$$
E=\left\{E_{i}\right\}, i=\overline{1, I} ; \quad l=\left\{I_{n}\right\}, n=\overline{1, N},
$$

where $E$ - experts for organizing of the cluster digitalization, $l_{\mathrm{n}}-$ technical, intellectual, financial, economic, social and other indicators.

At the second stage, the ranking of indicators for each alternative project is carried out and the coefficients of their importance are determined:

$$
W_{j}=\frac{2 \cdot(K-R+1)}{(K+\mathbb{1}) \cdot K},
$$

where $K$ - number of indicators, $R$ - rank of indicators.

In the third stage, the advantages of each local innovation project are evaluated, and projects are selected for maximum assessment.

$$
P=\sum_{i=1}^{k} W_{i} \cdot I_{n}^{y},
$$

where $I_{m}^{y}$ - weight of the indicator, $W_{\mathrm{i}}-$ the indicator brought to the computing system.

During the developing or choosing the method of structuring the goals and functions of the cluster as a complex economic system for the introduction of 
digitalisation of economic processes, it is necessary to take into account its state as a functioning economic system, the degree of development and interaction of its elements. Important is the formalization of the hierarchical components of the cluster, which allows achieving the required accuracy of the description based on the application of mathematical methods and structural studies [8]. In carrying out a systematic analysis of the purposes and functions of cluster systems, it is expedient, in our opinion, to use a methodology based on a system concept that takes into account the goal setting and the effects of the environment at a certain stage of development. Then system $\mathrm{C}$ takes the form:

$$
C \stackrel{\text { 然 }}{=}<B_{v} S_{v} Z_{v} E R_{x} G T>\text {, }
$$

where $B-$ set of system elements; $S$ - set of interconnections between elements; $Z$ - system targets; $E R$ the environment in which the system is located; $G T$ - system existence period that affects the process of forming goals.

Adoption of such a structuring concept allows to take into account all the important goals, functions and tasks of digitalization both in the internal environment of the cluster and in interaction with other systems: research institutions, educational institutions, suppliers, buyers, state authorities, etc. The beginning of the practical implementation of this concept ensured the efficiency of cluster systems functioning of Khmelnytskyi different industries (construction, sewing and tourism) by $7-15 \%$ by the use of digital technologies and reduction of expenses for marketing and advertising, logistic costs and wider use of electronic commerce and other elements virtualization business. Digitalization involves organizational changes in the cluster structure, as not only leading enterprises will form its center (core), but research institutions, higher educational institutions, information-computer and technological centers as well (Fig. 2).

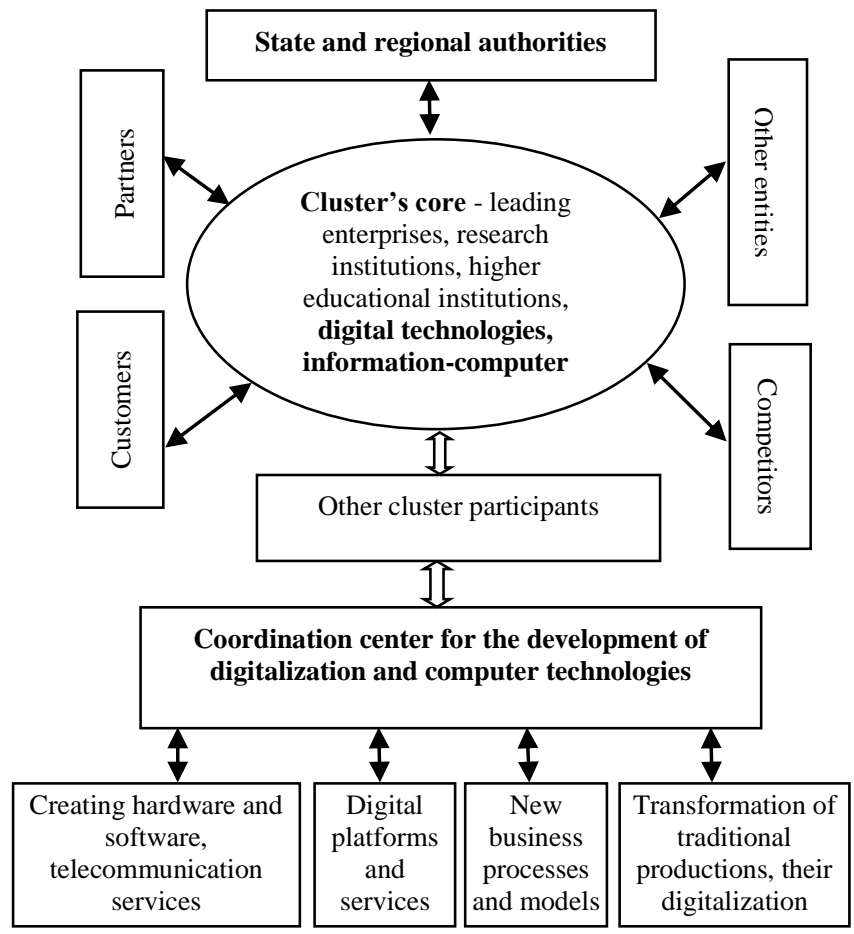

Fig. 2. Cluster structure under conditions of economy digitization
A sound choice of technology platform will ensure uniting and optimization of each part of value creating; qualitative change of traditional fundamental processes; identifying new, more efficient ways of doing business and better meeting the needs of employees and customers.

\section{CONCLUSION}

In the end, it should be noted that modern business and new economy type must overcome the resistance to change on a basis of independent scientific and technological research, having this as a cultural digital imperative, to be successful in the digital transformation model. Digital transformation is a daunting task. Countries that have reached the highest levels of digital maturity had to deal with complex cultural, organizational, and technical problems, and only taking into account all these factors made these transformations successful. Today in order to become digital leaders in specific areas of economy, it is necessary to prioritize digital projects that implement certain organizational structures, the main ones being cluster systems. Active deployment of high-speed networks depends on state incentives and its cooperation with science and business. Clusters are the best environment to achieve the objectives and goals of such cooperation as cluster structures possess powerful potential for innovations generation and implementation, including digital technologies principles.

\section{REFERENCES}

[1] M. P. Voynarenko, Clusters in the economy of Ukraine. Khmelnytskyi, Ukraine: KhNU, 2014.

[2] V. M. Geyets. "Ukraine Innovation 2020: National Report", NAS of Ukraine, 2015.

[3] I. Odotyuk. "Domestic industry of high technology, knowledge, innovation, investment factors of its formation and development ", National Library of Ukraine, vol. 11, pp. 21-33, 2011.

[4] O. I. Prodius. "Priority areas of structure formation of high-tech industrial production in Ukraine", Proceedings of the Odessa Polytechnic University, vol. 2 (26). pp. 245-249, 2006.

[5] L. V. Shynkaruk, et. al. "The structural transformation of the economy Ukraine: dynamics, contradictions and influence on economic development": research repor. NAS of Ukraine, SI «Institute of Economics and forecasting of NAS of Ukraine». 2015.

[6] M. P. Voynarenko, Clusters in the Institutional Economics. Monograph. Schweinfurt, Germany: Time Realities Scientific Group UG (haftungsbeschränkt), 2018.

[7] M. Voynarenko, L. Dzhuliy, and L. Yemmchuk. "The influence of information technologies on the development of modern social and economic systems", Scientific development and achievements: kollektive monographie. London: Science, Publishing, 2018.

[8] M. P. Voynarenko, and L. V. Yemchuk. "High technology clusters as technology development innovation centers", International journal of economics and society. vol. 2, no. 7, pp. 38-49, 2016.

[9] V. I. Loyko, E. V. Lutsenko, and A. I. Orlov, Modern Digital Econom, Krasnodar: Kub-GAU, 2018.

[10] V. Babenko, I. Perevozova, O. Mandych, T. Kvyatko, O. Maliy, and I. Mykolenko, "World informatization in conditions of international globalization: factors of influence”, Global. J. Environ. Sci. Manag., vol. 5(SI), pp. 172-179, 2019.

[11] V. Kobets, V. Yatsenko, and M. Voynarenko, "Cluster Analysis of Countries Inequality due to IT Development", in ICTERI 2019. Part II: 7th International Workshop on Information Technologies in Economic Research (ITER 2019). Kherson, June 12-15, 2019, pp. 405-420.

[12] A. N. Asaul, B. A. Dongak, "Priority Directions of Cluster Organization of Business Activities of the Republic of Tyva", Fundamental Research, no. 11-21, pp. 377-382, 2014. 